\title{
Kajian Penggunaan Metode Empiris dalam Menentukan Debit Banjir Rancangan pada Perencanaan Drainase (Review)
}

\author{
Ahmad Herison ${ }^{1, *}$, Yuda Romdania ${ }^{1}$, Ofik Taufik Purwadi ${ }^{1}$, Rahmat Effendi ${ }^{1}$ \\ ${ }^{1}$ Jurusan Teknik Sipil, Universitas Lampung, Bandar Lampung \\ Koresponden*, Email: ahmadherison@yahoo.com
}

\begin{tabular}{|c|c|}
\hline Info Artikel & Abstract \\
\hline $\begin{array}{l}\text { ajukan } 17 \text { Juli } 2018 \\
\text { perbaiki } 14 \text { Agustus } 2018 \\
\text { setujui } 22 \text { Oktober } 2018\end{array}$ & $\begin{array}{l}\text { Water was the most important factor, if not managed properly can cause a harm, one of which } \\
\text { was flood. Prevention of flood by optimizing drainage channels. The purpose was to review } \\
\text { previous research on drainage planning, especially method used to calculate discharge flood } \\
\text { design. The methods used were: Rational method, Weduwen method, Haspers method and } \\
\text { Melchior method. Determination of each method depends on rainfall data, flow characteristics, } \\
\text { and discharge data. Based on review, it was for calculating the design flood discharge was } \\
\text { based on the area of the catchment area. The research area that has wide DAS } 0,53 \text { Ha to } 97,34 \\
\text { Ha using rational method, 392,1 Ha area using method of Weduwen, 77,088,8 Ha area using }\end{array}$ \\
\hline $\begin{array}{l}\text { drainage, flood } \\
\text { nethod, melchior }\end{array}$ & $\begin{array}{l}\text { Melchior method. The conclusion was the calculation of flood discharge design with a } \\
\text { watershed area of less than } 300 \mathrm{Ha} \text { using the Rational method. }\end{array}$ \\
\hline
\end{tabular}

\begin{abstract}
Abstrak
Air merupakan faktor terpenting, apabila tidak dikelola dengan baik dapat menimbulkan kerugian, salah satunya adalah banjir. Pencegahan banjir dengan mengoptimalkan saluran drainase. Kegiatan ini bertujuan untuk mereview penelitian terdahulu mengenai perencanaan drainase, khususnya metode yang dipakai untuk menghitung debit banjir rancangan. Metode yang digunakan antara lain: Metode Rasional, Weduwen dan Melchior. Penetapan masing masing metode bergantung pada data hujan, karakteristik daerah aliran, dan data debit. Berdasarkan review, penetapan metode untuk menghitung debit banjir rancangan didasarkan pada luas daerah tangkapan airnya. Lokasi penelitian yang memiliki luas DAS 0,53 ha sampai 97,34 ha menggunakan Metode Rasional, luas Daerah Aliran Sungai (DAS) 392, 1 ha menggunakan Metode Weduwen, luas DAS 77.088,8 ha menggunakan Metode Melchior. Kesimpulannya adalah, perhitungan debit banjir rancangan dengan luas DAS kurang dari 300 ha menggunakan Metode Rasional.
\end{abstract}

Kata kunci: drainase, debit banjir rancangan, review, Metode Rasional berasal dari air hujan, rembesan, maupun kelebihan air irigasi dari suatu kawasan atau lahan, sehingga fungsi kawasan atau lahan tidak terganggu. Hal tersebut juga merupakan suatu usaha untuk mengontrol kualitas air tanah dalam kaitannya dengan salinitas. Jadi, drainase tidak hanya menyangkut air permukaan tetapi juga air tanah [5]. Perencanaan drainase membutuhkan data debit sebagai parameter kapasitasnya. Untuk itu perhitungan debit rancangan yang dipakai harus sesuai. Debit rencana (Qr) adalah debit dengan periode ulang tertentu yang diperkirakan akan melalui suatu sungai atau bangunan air [6].

Kegiatan ini bertujuan untuk mereview beberapa penelitian terdahulu mengenai perencanaan drainase, khususnya metode yang dipakai untuk menghitung debit banjir rancangan yang akan digunakan pada perencanaan drainase pada penelitian selanjutnya. 
Beberapa metode yang dapat digunakan untuk perhitungan debit banjir rancangan antara lain: Metode Rasional, Weduwen, Haspers dan Melchior. Menurut Kamiana [6], penetapan masing-masing metode dalam perhitungan debit banjir rencana, secara umum bergantung pada ketersediaan data. Data yang dimaksud antara lain data hujan, karakteristik daerah aliran, dan data debit.

\section{Metode}

a. Metode Rasional

Metode rasional adalah metode lama yang masih digunakan hingga sekarang untuk memperkirakan debit puncak (peak discharge). Ide yang melatar belakangi metode rasional adalah jika curah hujan dengan intensitas I terjadi secara terus-menerus, maka laju limpasan langsung akan bertambah sampai mencapai waktu konsentrasi tc. Waktu konsentrasi tc tercapai ketika seluruh bagian DAS telah memberikan kontribusi aliran di outlet. Laju masukan pada sistem adalah hasil curah hujan dengan intensitas I pada DAS dengan luas A. Nilai perbandingan antara laju masukan dengan laju debit puncak (Qp) yang terjadi pada saat tc dinyatakan sebagai run off coefficient (C) dengan nilai $0<=\mathrm{C}<=1$ [7].

Beberapa asumsi dasar untuk menggunakan metode rasional adalah:

1. Curah hujan terjadi dengan intensitas yang tetap dalam jangka waktu tertentu, setidaknya sama dengan waktu konsentrasi.

2. Limpasan langsung mencapai maksimum ketika durasi hujan dengan intensitas tetap sama dengan waktu konsentrasi.

3. Koefisien run off dianggap tetap selama durasi hujan.

4. Luas DAS tidak berubah selama durasi hujan [8].

Rumus ini adalah rumus yang tertua dan yang terkenal di antara rumus - rumus empiris lainnya. Rumus ini banyak digunakan untuk sungai-sungai biasa dengan daerah pengaliran yang luas dan juga untuk perencanaan drainase daerah pengaliran yang relatif sempit. Bentuk umum rumus rasional ini adalah sebagai berikut:

$\mathrm{Q}=$ 0,2778.C.I.A

Dimana:

$\mathrm{Q}=$ Debit banjir maksimum $\left(\mathrm{m}^{3} / \mathrm{det}\right)$

$\mathrm{C}=$ Koefisien pengaliran/limpasan

$\mathrm{I}=$ Intensitas curah hujan rata-rata $(\mathrm{mm} / \mathrm{jam})$

$\mathrm{A}=$ Luas daerah pengaliran $\left(\mathrm{km}^{2}\right)$

Arti rumus ini dapat segera diketahui yakni jika terjadi curah hujan selama 1 jam dengan intensitas $1 \mathrm{~mm} / \mathrm{jam}$ dalam daerah seluas $1 \mathrm{~km}^{2}$, maka debit banjir sebesar 0,2778 m³/det dan melimpas selama 1 jam [8].

b. Metode Weduwen

Metode ini khusus digunakan untuk menghitung debit banjir dengan luas DAS $<100 \mathrm{~km}^{2}$ [9]. Adapun langkahlangkah perhitungannya adalah:

- Menghitung bersarnya debit banjir kala ulang dengan menggunakan rumus:

$Q n=\alpha \times \beta \times q n \times A$

Dengan:

Qn = Debit banjir rencana

$\alpha=$ Koefisien limpasan

$\beta=$ Koefisien pengurangan daerah hujan

qn $=$ Curah hujan

$\mathrm{A}=$ Luas DAS

- Menghitung nilai koefisien limpasan:

$\alpha=1-\frac{4,1}{b \times q n+7}$

- Menghitung nilai koefisien pengurangan daerah hujan:

$\beta=\frac{120+\frac{t+1}{t+9} A}{120+A}$

- Menghitung curah hujan:

$q n=\frac{R T}{240} \frac{67,65}{t+1,45}$

Dengan:

RT = Curah hujan rencana kala ulang

- Menghitung lama hujan:

$t=0,25 \times L \times Q^{-0,125} \times I^{-0,25}$

Dengan:

$\mathrm{t}=$ Lama hujan

$\mathrm{L}=$ Panjang sungai

Qn = Debit banjir

$\mathrm{I}=$ Kemiringan rata-rata dasar sungai

Dengan menggunakan cara coba-coba dengan menggunakan nilai t, sehingga akan diperoleh nilai debit banjir rencana.

\section{c. Metode Melchior}

Metode Melchior ini digunakan untuk memperkirakan debit banjir rancangan untuk DAS yang luasnya lebih dari $100 \mathrm{~km}^{2}$. Adapun prosedur perhitungannya menurut Subarkah [10] adalah sebagai berikut:

- Lukis elips yang mengelilingi DAS dengan sumbu panjang (kira-kira) 1,5 kali sumbu pendek dan hitung luasnya dengan rumus:

$$
n F=0,25 \cdot \pi \cdot L_{1} \cdot L_{2}
$$

- Mengukur luas Daerah Aliran Sungai dengan planimeter $\left(\mathrm{km}^{2}\right)$ 
- Menghitung rata-rata kemiringan dasar sungai dengan rumus:

$$
I=\frac{H}{0,9 \cdot L}
$$

- Menghitung harga $\beta_{1}$ dengan menggunakan persamaan:

$$
n F=\frac{1970}{\beta_{1}-0,12}-3960+\left(1720 \times \beta_{1}\right)
$$

- Menaksir besarnya hujan maksimum sehari $\left(\mathrm{R}_{0}\right.$, $\mathrm{m}^{3} / \mathrm{detik} / \mathrm{km}^{2}$ )

- Menghitung besarnya debit $\left(\mathrm{Q}_{0}\right)$ dengan persamaan:

$$
Q_{0}=\beta_{1} \cdot R_{0} \cdot A
$$

- Menghitung kecepatan aliran (V) dengan persamaan:

$$
V=1,31 \cdot\left(Q_{0} \cdot I^{2}\right)^{0,2} \cdot\left(\frac{\alpha}{0,52}\right)^{0,2}
$$

- Menghitung waktu tiba banjir (Tc) dengan persamaan:

$$
T c=\frac{10 L}{36 V}
$$

- Menentukan koefisien $\beta_{2}$ dari tabel hubungan Tc dan $\mathrm{nF}$, sehingga koefisien reduksi $\beta$ dapat dihitung dengan persamaan:

$$
\beta=\beta_{1} \times \beta_{2}
$$

- Menghitung harga $\mathrm{R}_{\mathrm{T}}$ dengan persamaan:

$$
R_{T}=\frac{10 \times \beta \times \mathrm{R}}{36 T c}
$$

- Mengontrol nilai $\mathrm{R}_{0}=\mathrm{R}_{\mathrm{T}}$, jika nilainya tidak sama diulang mencoba nilai $\mathrm{R}_{0}$ sampai akhirnya nilai tersebut sama.

- Menghitung debit banjir rancangan berdasarkan kala ulang dengan menggunakan persamaan:

$$
Q T=\frac{\alpha \times R \times R T \times A}{200}
$$

Dimana:

$\mathrm{QT}=$ Debit banjir rancangan $\left(\mathrm{m}^{3} /\right.$ detik)

$\mathrm{A}=$ Koefisien pengaliran Melchior berkisar 0,42 -

0,62 dianjurkan menggunakan 0,52

$\mathrm{B}=$ Koefisien reduksi

$\mathrm{R}=$ Curah hujan rancangan $\left(\mathrm{m}^{3} /\right.$ detik)

$\mathrm{RT}=$ Hujan maksimum sehari $\left(\mathrm{m}^{3} / \operatorname{detik} / \mathrm{km}^{2}\right)$

$\mathrm{A}=$ Luas daerah pengaliran $\left(\mathrm{km}^{2}\right)$

$\mathrm{nF}=$ Luas elips $(\mathrm{km})$

L1 = Panjang sumbu besar elips $(\mathrm{km})$

L2 = Panjang sumbu kecil elips $(\mathrm{km})$

$\mathrm{L}=$ Panjang alur suungai utama $(\mathrm{km})$

Tc = Waktu tiba banjir (jam)

$\mathrm{V}=$ Kecepatan aliran (m/detik)

$\mathrm{I}=$ Kemiringan rata - rata sungai

$\mathrm{H}=$ Beda elevasi antara titik yang dimaksud d. Metode Haspers (Marcelia et al, 2014) [9]

Prosedur perhitungannya adalah:

- Menentukan besarnya koefisien pengaliran:

$$
\alpha=\frac{1+0,12 A^{0,7}}{1+0,075 A^{0,7}}
$$

- Menentukan koefisien reduksi:

$$
\frac{1}{\beta}=1+\frac{T c+3,7 \cdot 10^{(-0,4 T c)}}{T c^{2}+15} \times \frac{A^{0,75}}{12}
$$

- Menghitung curah hujan maksimum:

$$
R t=\frac{r}{3,6 T c}
$$

- Dengan nilai r dapat dihitung berdasarkan nilai Tc:

$$
\begin{aligned}
& r=\frac{T c \times R_{24 \text { maks }}}{T c+1-0,008(260-R)(2-T c)^{2}} \text {; bila Tc }<2 \text { jam } \\
& r=\frac{T c \times R_{24} \text { maks }}{T c+1} ; \text { bila } 2 \text { jam }<\text { Tc }<19 \text { jam } \\
& r=0,707 \times R_{24 \text { maks }}(T+1) \text {; bila } 19 \text { jam }<\text { Tc }<30 \\
& \text { hari }
\end{aligned}
$$

- Menghitung debit banjir rencana berdasarkan persamaan haspers:

$$
Q=\alpha \times \beta \times R t . A
$$

Dimana:

$\mathrm{Q}$ = Debit banjir rencana dengan periode ulang $\mathrm{T}$ tahun, $\mathrm{m}^{3} /$ detik

$\alpha=$ Koefisien pengaliran
$\beta=$ Koefisien reduksi
$\mathrm{Rt}=$ Limpasan hujan maksimum per $\mathrm{km}^{2}$ daerah tadah hujan dengan kala ulang, $\mathrm{T}$ tahun, $\mathrm{m}^{2} / \mathrm{dt} / \mathrm{km}^{2}$

$\mathrm{R}$ = Curah hujan rencana dengan kala ulang $\mathrm{T}$ tahun, $\mathrm{mm}$

$$
\begin{aligned}
& \mathrm{A}=\text { Luas daerah pengaliran sungai, } \mathrm{km}^{2} \\
& \mathrm{I}=\text { Kemiringan sungai rata-rata }
\end{aligned}
$$

\section{Hasil dan Pembahasan}

Kawasan Perumnas Talang Kelapa memiliki luas \pm 42,76 ha sehingga perencanaan drainase pada kawasan Perumnas Talang Kelapa di Sub DAS Lambidaro Kota Palembang menggunakan metode rasional untuk menghitung debit rancangan. Berdasarkan hasil penelitian, terdapat 24 dari 51 saluran yang sudah tidak mampu mengalirkan debit air [11].

Banjir dan genangan pada badan jalan masih terjadi di kawasan Desa Sariharjo, lokasi terparah pada Jalan Palagan Tentara Pelajar (Gambar 1). Genangan disebabkan oleh saluran drainase yang tidak mampu lagi menampung air hujan, sehingga melimpas ke badan jalan dan pemukiman penduduk, menyebabkan kerugian berupa terganggunya arus lalulintas (kemacetan). Oleh karena itu, perlu dilakukan penelitian untuk mengevaluasi kapasitas saluran yang ada. Pada lokasi penelitian, luas tangkapan air terbesar adalah sebesar 97,34 ha. Perhitungan banjir rancangan dihitung 
dengan cara rasional, sedangkan debit dihitung dengan persamaan kontinuitas, dengan menggunakan persamaan kecepatan Manning's. Berdasarkan analisis banjir jalan terdapat 5 dari 40 saluran yang tidak mampu menampung banjir 5-tahunan [12].

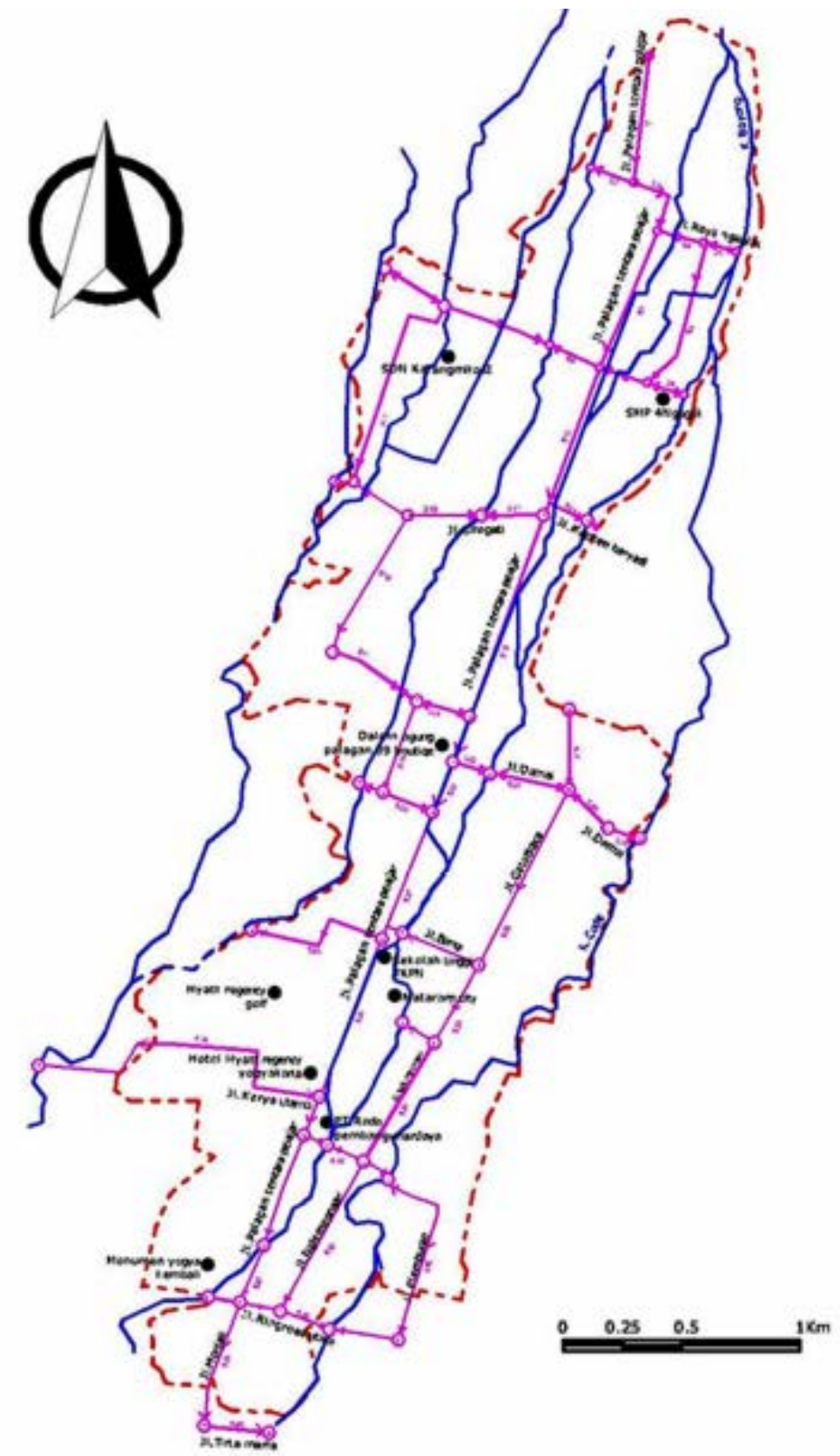

Gambar 1. Pola Jaringan Drainase Desa Sariharjo Sumber: Sulistiono [12]

Sebagian dari saluran yang ada di Kampus USU tidak berfungsi lagi sebagaimana mestinya, baik disebabkan oleh daya tampung yang lebih kecil dari debit yang ada, kurangnya perawatan maupun sistem pengaliran dan pembuangan yang tidak sesuai lagi (Gambar 2). Debit banjir 10 tahun dihitung dengan Metode Rasional. Hasil penelitian dan pengolahan data mengungkapkan bahwa di beberapa saluran drainase limpasan melimpah diakibatkan karena mengecil penampang. Banjir atau genangan yang besar dan tinggi yang terjadi di Kampus USU juga dipengaruhi besarnya sedimen yang terjadi saat di lapangan serta kurangnya resapan air pada daerah-daerah 
terjadi banjir akibat kurang pemeliharaan pada saluran drainase [13].

Pertumbuhan Kota Gresik disertai bertambahnya jumlah penduduk dan berkembangnya industri menimbulkan dampak pada siklus hidrologi dan mengurangi kawasan resapan sehingga mengakibatkan banjir/genangan. Kawasan yang rawan banjir yaitu di daerah pasar kota. Luas DAS dari lokasi penelitian yaitu sebesar 65,87 ha. Untuk menghitung besarnya debit air hujan dalam merencanakan drainase perkotaan umumnya dilakukan dengan metode rasional. karena luasan relatif daerah aliran yang tidak terlalu luas, kehilangan air sedikit dan waktu konsentrasi relatif pendek [5]. Hasil kajian diperoleh bahwa sistem drainase Kali Tutup Barat Kabupaten Gresik tidak mampu mengatasi limpasan (Gambar 3). Dengan lahan yang ada kapasitas bozem dapat menampung debit limpasan sebesar $4.444 \mathrm{~m}^{3}$ sedangkan sumur injeksi sebesar 706,5 $\mathrm{m}^{3}$ [14].

Dusun Kumu bagian dari Desa Rambah merupakan wilayah permukiman masyarakat yang masuk Kecamatan Rambah Hilir. Luas daerah tangkapan air terbesar sebesar 0,53 ha. Di daerah ini merupakan daerah yang dekat dengan sungai. Keadaan ini menyebabkan daerah tersebut akan sangat terpengaruh bila terjadi air meluap atau kapasitas air melebihi kapasitas aliran sungai.

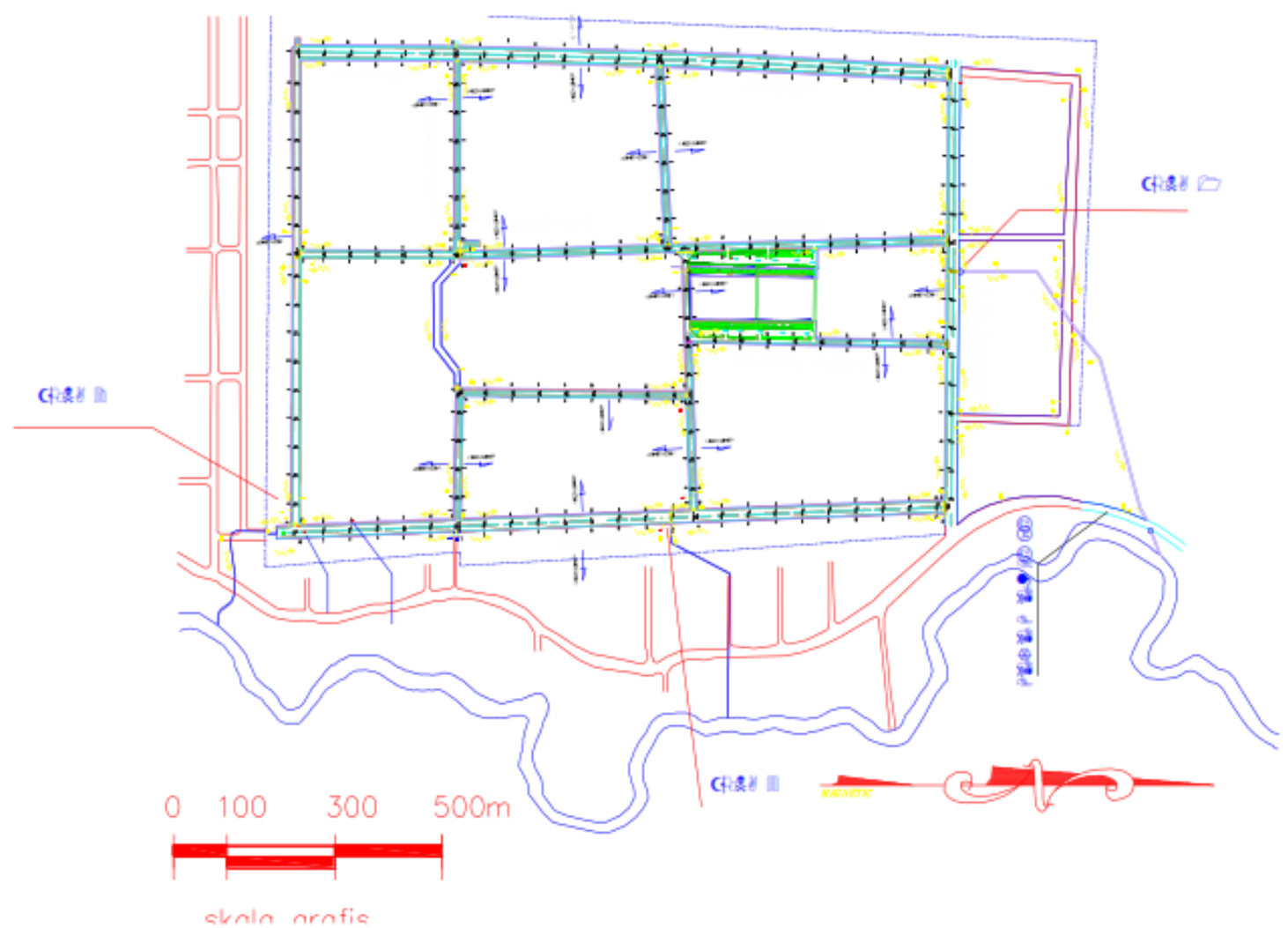

Gambar 2. Lokasi kampus USU dan sistem daerah tangkapan air Sumber: Yudi M [13]

Apabila tidak dilakukan tindakan untuk mengatasi masalah banjir ini akan membawa dampak lebih buruk lagi, yaitu terhambatnya perkembangan perekonomian dan sosial budaya masyarakat. Penelitian di lokasi ini menggunakan metode rasional dalam perhitungan debit banjir rancangannya. Dari hasil analisa, didapatkan dimensi saluran untuk Dusun Kumu, dengan dimensi Tinjauan $1 \mathrm{~b}=1,7 \mathrm{~m}, \mathrm{~h}=1,5 \mathrm{~m}$, ba = 3,496 $\mathrm{m}$, Tinjauan 2 dan Tinjauan $3 \mathrm{~b}=1,7 \mathrm{~m}, \mathrm{~h}=1,4 \mathrm{~m}$, ba $=3,150$ $\mathrm{m}[15]$.
Permasalahan drainase di Kota Nanga Bulik lebih disebabkan oleh kurangnya kemampuan saluran drainase dalam menampung debit air yang ada, saluran yang ada juga tidak menyambung/terputus dengan saluran lainnya, serta kurang terawat dan tidak terpeliharanya saluran-saluran drainase tersebut (Gambar 4). Metode Rasional Modifikasi digunakan dalam menghitung debit banjir rancangan. Perhitungan debit dibagi dalam beberapa wilayah karena luas wilayah yang terlalu besar $\left(6,414 \mathrm{~km}^{2}\right)$ dengan wilayah terbesar sebesar 74,6 ha. Hasil analisa menunjukkan bahwa 
terdapat 26 saluran, namun 20 saluran tidak mencukupi dengan debit rancangan yang ada [16].

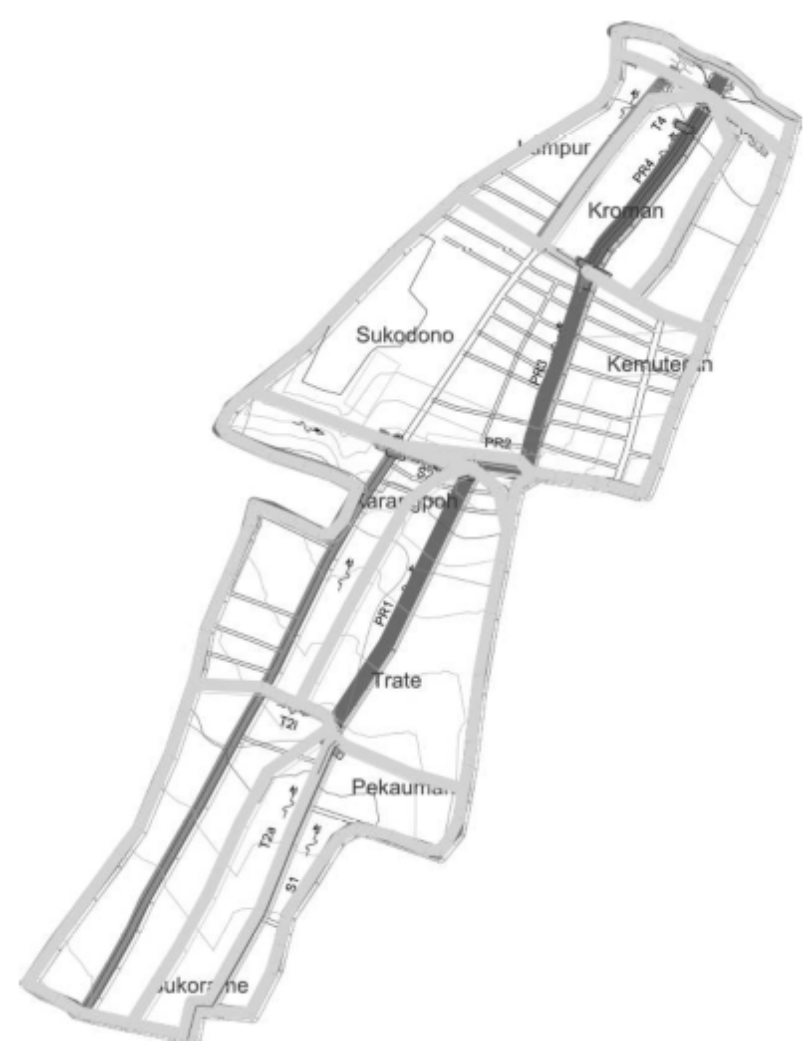

Gambar 3. Peta DAS Kali Tutup Barat

Sumber: Ubaidillah et al14]

Perkembangan kawasan kampus Universitas Lampung khususnya Fakultas Teknik yang tidak diikuti dengan perkembangan sistem drainase yang memadai, sehingga mengakibatkan pada setiap musim penghujan terjadi genangan. Genangan sering terjadi dibagian badan jalan depan gedung $\mathrm{E}$ Fakultas Teknik dan disamping mushola Fakultas Teknik, hal ini karena kurang baiknya sistem drainase yang ada dan tidak tersedianya kolam tampungan yang memadai. Fakultas Teknik Universitas Lampung memiliki luas DAS sebesar 50,13 ha, sehingga dalam perhitungan debit banjirnya menggunakan metode rasional. Nilai Qhujan adalah 2,1172 $\mathrm{m}^{3} /$ detik sedangkan nilai $Q_{\text {teoritis }}$ adalah 0,0833 $\mathrm{m}^{3} /$ detik. Karena Qhujan lebih besar daripada Q Qteoritis, dapat disimpulkan bahwa saluran drainase eksisting di Fakultas Teknik Universitas Lampung sudah tidak cukup lagi untuk menampung debit banjir yang ada [17].

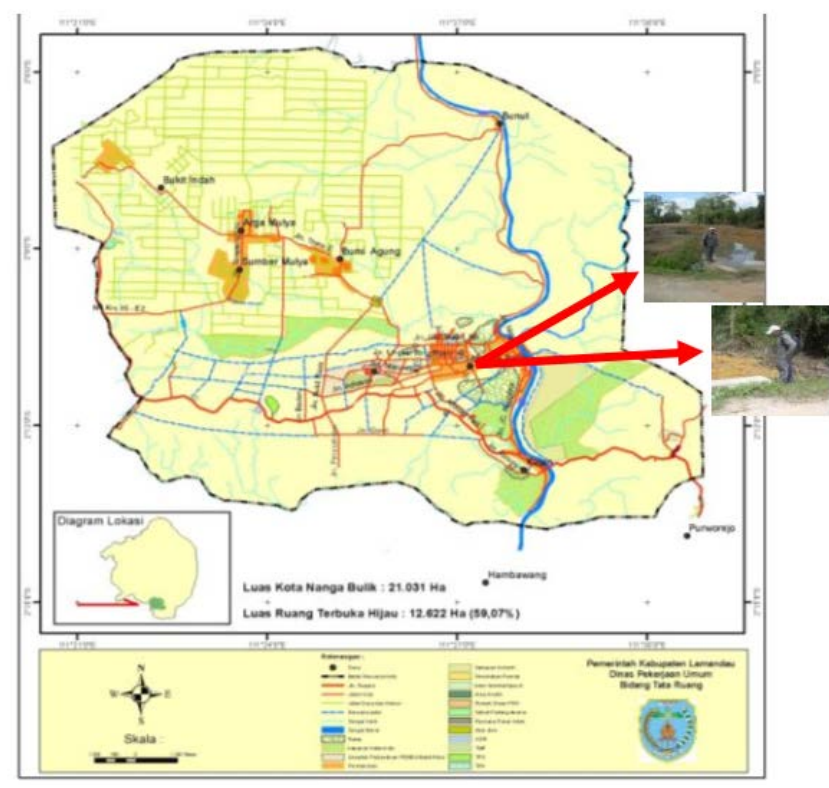

Gambar 4. Peta Kecamatan Bulik

Sumber: D.A.T Saputro et al [16]

Metode yang digunakan pada penelitian untuk menghitung debit banjir rancangan di DAS Bangga menggunakan metode Rasional, metode Melchior, dan metode Weduwen dan dibandingkan terhadap debit banjir rancangan data debit sungai menggunakan metode distribusi hidrologi yang sesuai dengan parameter statistik. Sungai Bangga memiliki luas DAS sebesar 69,04 $\mathrm{km}^{2}$ [9].

Hasil yang diperoleh dari olahan data curah hujan menggunakan metode Rasional, metode Melchior, metode Haspers dan Metode Weduwen terhadap nilai debit banjir rancangan hasil olahan data debit terukur Sungai Bangga adalah untuk kala ulang 2 tahun penyimpangan terbesar diperoleh menggunakan Metode Weduwen sebesar 92,86 \%, sedangkan penyimpangan terkecil diperoleh dengan menggunakan Metode Rasional sebesar 23,41\%, begitupun untuk kala ulang 5 tahun sebesar $5.21 \%$, untuk kala ulang 10 tahun sebesar -2.38\%, untuk kala ulang 25 tahun sebesar -9.40 $\%$, untuk kala ulang 50 tahun sebesar $-13.38 \%$, dan untuk kala ulang 100 tahun sebesar $-16.64 \%$, sehingga Metode Rasional dapat dijadikan acuan dalam perencanaan bangunan-bangunan air pada Daerah Aliran Sungai Bangga (Tabel 1) [9].

Sungai Negara adalah salah satu sungai di Provinsi Kalimantan Selatan yang mempunyai luas DAS sebesar 3.921 $\mathrm{km}^{2}$. Penelitian yang dilakukan pada lokasi ini menggunakan metode studi pustaka dan melakukan analisis terhadap data curah hujan untuk mendapatkan debit banjir pada daerah aliran Sungai Negara dengan Metode Rasional, Der Weduwen dan Haspers serta melakukan analisis frekuensi terhadap data debit terukur. Hasil perhitungan data curah hujan didapatkan bahwa penyimpangan terkecil terjadi terhadap Metode Der Weduwen 
yaitu sebesar 38.28\% untuk kala ulang 2 tahun, 36.47\% untuk kala ulang 5 tahun, 36.04\% untuk kala ulang 10 tahun, 35.96\% untuk kala ulang 20 tahun, 36.17\% untuk kala ulang 50 tahun dan 36.50\% untuk kala ulang 100 tahun (Tabel 2). Oleh karena itu, Metode Der Weduwen dapat digunakan sebagai acuan untuk dalam perhitungan debit banjir rencana untuk merencanakan penanggulangan bencana banjir di Sungai Negara [18].

Tabel 1. Hasil Debit Rancangan Menggunakan Data Hujan dan Data Debit

\begin{tabular}{|c|c|c|c|c|c|}
\hline \multirow{2}{*}{$\begin{array}{l}\text { Kala } \\
\text { Ulang } \\
\text { (Tahun) }\end{array}$} & \multicolumn{5}{|c|}{ Debit Banjir Rancangan (m³/det) } \\
\hline & $\begin{array}{l}\text { Rasiona } \\
\text { l }\end{array}$ & Melchior & Weduwen & Haspers & $\begin{array}{l}\text { Debit } \\
\text { Terukur }\end{array}$ \\
\hline 2 & 8,10 & 17,52 & 71,69 & 156,01 & 6,56 \\
\hline 5 & 10,00 & 27,14 & 94,84 & 192,74 & 9,51 \\
\hline 10 & 11,18 & 34,16 & 110,00 & 215,37 & 202,15 \\
\hline 25 & 12,56 & 43,52 & 128,68 & 242,06 & 13,86 \\
\hline 50 & 13,54 & 50,85 & 142,38 & 260,95 & 15,63 \\
\hline 100 & 14,48 & 58,46 & 155,89 & 279,08 & 17,37 \\
\hline
\end{tabular}

Sumber: Marcelia et al, [9]

Sungai Ranoyapo adalah salah satu sungai di Sulawesi Utara yang rawan terhadap banjir. Daerah aliran sungainya mencakup beberapa daerah yang ada di Kabupaten Minahasa Selatan dengan luas DAS 770,888 km². Analisis debit banjir rencana menggunakan Metode Rasional, Melchior, Weduwen, dan Haspers dibandingkan dengan metode analisis frekuensi. Dari hasil analisis, debit banjir rencana dengan berbagai kala ulang di setiap metode, memberikan hasil yang beragam. Hasil yang terkecil adalah dengan menggunakan Metode Melchior [19].

Pada penelitian Marcelia et al [9] yang membandingkan metode Rasional, Melchior, Weduwen, dan Haspers dengan data dari debit terukur pada lokasi penelitian yang memiliki DAS seluas 69,04 ha, hasil perhitungan debit yang paling mendekati terdapat pada metode Rasional dengan faktor koreksi sebesar 1,04, sedangkan hasil yang paling jauh terdapat pada metode Haspers dengan faktor koreksi sebesar 0,1 .
Tabel 2. Debit Banjir Rencana Menggunakan Data Curah Hujan dan Data Debit

\begin{tabular}{lllll}
\hline $\begin{array}{l}\text { Kala } \\
\text { Ulang } \\
\text { (Tahun) }\end{array}$ & \multicolumn{4}{l}{ Debit Banjir Rancangan $\left(\mathrm{m}^{3} / \mathrm{det}\right)$} \\
\cline { 2 - 5 } & Rasional & $\begin{array}{l}\text { Der } \\
\text { Weduwen }\end{array}$ & Haspers & $\begin{array}{l}\text { Debit } \\
\text { Terukur }\end{array}$ \\
\hline 2 & 214,31 & 579,43 & 1026,53 & 419,02 \\
5 & 270,04 & 740,97 & 1435,32 & 542,94 \\
10 & 306,94 & 850,24 & 1631,43 & 624,98 \\
25 & 342,34 & 956,74 & 1819,55 & 703,68 \\
50 & 388,13 & 1096,92 & 2036,05 & 805,55 \\
100 & 422,47 & 1203,73 & 2245,52 & 881,89 \\
\hline
\end{tabular}

Sumber: Utami [18]

Pada penelitian Lestari [18] DAS yang diteliti seluas 3.921 $\mathrm{km}^{2}$ atau 392.100 ha, hasil yang paling mendekati debit terukur terdapat pada metode Weduwen dengan faktor koreksi sebesar 0,73, sedangkan hasil yang paling jauh terdapat pada metode Haspers dengan faktor koreksi sebesar 0,39.

Pada penelitian J. A. Robot et al [ 19] DAS yang diteliti seluas $770,888 \mathrm{~km}^{2}$ atau $77.088,8$ ha, hasil yang paling mendekati debit terukur terdapat pada metode Melchior, sedangkan hasil yang paling jauh terdapat pada metode Haspers (Tabel 3).

Dari hasil review beberapa jurnal yang telah dibahas diatas, dapat disimpulkan bahwa penetapan metode untuk menghitung debit banjir rancangan didasarkan pada luas daerah tangkapan airnya. Pada Tabel $\mathbf{4}$ dapat dilihat bahwa lokasi penelitian yang memiliki luas DAS 0,53 ha sampai 97,34 ha menggunakan metode rasional, luas DAS 392,1 ha menggunakan metode Weduwen, luas DAS 77.088,8 ha menggunakan metode Melchior.

Beberapa ahli saling berbeda pendapat mengenai batasan Luas DAS maksimum untuk penggunaan metode rasional. Menurut Goldman dalam Suripin [5], Metode Rasional dapat digunakan untuk daerah pengaliran $<300$ ha. Menurut Ponce dalam Bambang [20], Metode Rasional dapat digunakan untuk daerah pengaliran $<2,5 \mathrm{Km}^{2}$.

Tabel 3. Debit Banjir Rencana untuk Setiap Metode dengan Berbagai Kala Ulang

\begin{tabular}{llllll}
\hline \multirow{2}{*}{ Periode Ulang (Tr) } & \multirow{2}{*}{ Analisis Frekuensi } & Metode Empiris & & \\
\cline { 3 - 6 } & & Metode Rasional & Metode Melchior & Metode Weduwen & Metode Haspers \\
\hline 1 & 84,5546 & $1.375,508$ & 649,238 & 779,433 & 786,625 \\
2 & 153,0285 & $2.639,652$ & $1.245,912$ & $1.495,762$ & $1.509,563$ \\
5 & 230,0622 & $3.625,359$ & $1.711,164$ & $2.054,315$ & $2.073,270$ \\
10 & 276,3266 & $4.360,840$ & $2.058,310$ & $2.471,075$ & $2.493,876$ \\
50 & 424,8026 & $6.232,901$ & $2.941,920$ & $3.531,882$ & $3.564,471$ \\
100 & 489,7453 & $7.143,055$ & $3.371,511$ & $4.047,621$ & $4.084,969$ \\
\hline
\end{tabular}

Sumber: J.A. Robot et al[19] 
Tabel 4. Luas Daerah Tangkapan Air dan Metode yang Digunakan pada Penelitian

\begin{tabular}{|c|c|c|c|}
\hline \multirow[t]{2}{*}{ No. } & \multirow[t]{2}{*}{ Lokasi Penelitian } & Luas $\quad$ Daerah & Metode \\
\hline & & \multicolumn{2}{|l|}{ Tangkapan air } \\
\hline 1 & $\begin{array}{ll}\text { Perumnas } & \text { Talang }\end{array}$ & 42,76 ha & Rasional \\
\hline & Kelapa, Palembang & & \\
\hline 2 & Desa Sariharjo & 97,34 ha & Rasional \\
\hline 3 & $\begin{array}{l}\text { Kali Tutup Barat, } \\
\text { Gresik }\end{array}$ & 65,87 ha & Rasional \\
\hline 4 & $\begin{array}{l}\text { Dusun Kumu, } \\
\text { Rambah Hilir }\end{array}$ & 0,53 ha & Rasional \\
\hline 3 & Kota Nanga Balik & 74,6 ha & Rasional \\
\hline 4 & $\begin{array}{ll}\text { Fakultas } & \text { Teknik } \\
\text { Universitas } & \\
\text { Lampung } & \end{array}$ & 50,13 ha & Rasional \\
\hline 5 & Sungai Bangga & 69,04 ha & Rasional \\
\hline 6 & $\begin{array}{l}\text { Sungai Negara, } \\
\text { Kalimantan Selatan }\end{array}$ & 392.100 ha & Weduwen \\
\hline 7 & $\begin{array}{l}\text { Sungai Ranoyano, } \\
\text { Minahasa Selatan }\end{array}$ & $77.088,8$ ha & Melchior \\
\hline
\end{tabular}

Dalam Asdak [21], dijelaskan jika ukuran daerah pengaliran $>300$ ha, maka ukuran daerah pengaliran perlu dibagi menjadi beberapa bagian sub daerah pengliran. Dalam Suripin [5] dijelaskan penggunaan Metode Rasional pada daerah pengaliran dengan beberapa sub daerah pengaliran dapat dilakukan dengan pendekatan nilai $\mathrm{C}$ gabungan atau $\mathrm{C}$ ratarata dan intensitas hujan dihitung berdasarkan waktu konsentrasi yang terpanjang.

Selain itu tertera pula pada Peraturan Menteri PU tentang penyelenggaraan sistem drainase perkotaan. Debit banjir rencana dihitung dengan metode rasional atau metode rasional yang telah dimodifikasi atau hidrograf satuan untuk daerah perkotaan/unit hydrograph for urban areas (PERMENPU, 2014) [22].

\section{Simpulan}

Luas DAS sangat berpengaruh pada metode yang akan digunakan dalam menghitung debit banjir rancangan. Untuk penelitian dengan luas DAS dengan luas $<300$ ha dapat menggunakan metode Rasional untuk perhitungan debitnya, karena hasil yang didapatkan akan lebih mendekati debit terukur.

\section{Daftar Pustaka}

[1] Xia Jun. dan Yongqin David Chen. 2001. Water Problems and Opportunities in the Hydrological Science in China. China: Hydrologial Science Journal.

[2] L. Bevere, et al. 2015. Natural catastrophes and manmade disaster in 2014: convectiveand winter storms generate most losses. Zurich: Swiss Re
[3] Neha Bansal., et al. 2015. Causes and Impact of Urban Flooding in Dehradun. Rorkee: International Journal of Current Research.

[4] T. Tingsanchali. 2012. Urban Flood Disaster Management. Nakhon Pathom: Elsevier.

[5] Suripin. 2004. Sistem Drainase Perkotaan yang Berkelanjutan. Yogyakarta: Andi.

[6] I. M. Kamiana. 2011. Teknik Perhitungan Debit Rencana Bangunan Air. Yogyakarta: Graha Ilmu.

[7] Febrina Girsang. 2007. Analisis Curah Hujan untuk Pendugaan Debit Puncak dengan Metode Rasional pada DAS Belawan Kabupaten Deli Serdang. Sumatera Utara: Universitas Sumatera Utara.

[8] Suyono Sosrodarsono, dan Kensaku Takeda, 2003. Hidrologi untuk Pengairan. Jakarta: Pradnya Paramita.

[8] M. P. Wanielista. 1990. Hydrology and Water Quality Control. Florida: John Wiley \& Sons.

[9] Marcelia, et al. 2014. Ketelitian Metode Empiris untuk Menghitung Debit Banjir Rancangan di DAS Bangga. Palu: Universitas Tadulako.

[10] Iman Subarkah. 1980. Hidrologi untuk Perencanaan Bangunan Air. Bandung: Idea Dharma

[11] D Farizi. 2015. Analisis dan Evaluasi Saluran Drainase pada Kawasan Perumnas Talang Kelapa di SubDAS Lambidaro Kota Palembang. Palembang: Universitas Sriwijaya.

[12] Bambang Sulistiono. dan A. F. Ardiyanto. 2016. Evaluasi Kapasitas Saluran Drainase Desa Sariharjo Ngaglik Sleman Yogyakarta. Yogyakarta: Universitas Islam Indonesia.

[13] Yudi Mardiansyah. dan A.P. Mulia Tarigan. 2012. Evaluasi Sistem Drainase Kampus Universitas Sumatera Utara. Medan: Universitas Sumatera Utara.

[14] Ubaidillah, et al. 2012. Studi Sistem Drainase Kali Tutup Barat Kabupaten Gresik Berbasis Konservasi untuk Penanganan Genangan. Malang: Universitas Brawijaya.

[15] Hamdan Lubis., et al. 2013. Perencanaan Saluran Drainase (Studi Kasus Desa Rambah). Riau: Universitas Pasir Pengaraian.

[16] D.A.T Saputro., et al. 2014. Perencanaan Drainase Perkotaan di Kota Nanga Bulik Kabupaten Lamandau Provinsi Kalimantan Tengah. Malang: Universitas Brawijaya.

[17] Riko Berli Ardian., et al. 2016. Study System Drainase di Fakultas Teknik Universitas Lampung. Lampung: Universitas Lampung.

[18] Utami Sylivia Lestari., 2016. Kajian Metode Empiris untuk Menghitung Debit Banjir Sungai Negara di Ruas 
Kecamatan Sungai Pandan (Alabio). Banjarmasin: Universitas Lambung Mangkurat.

[19] Jeffier Andrew Robot., et al. 2014. Analisis Debit Banjir Sungai Ranoyapo Menggunakan Metode HSS Gama-I dan HSS Limantara. Manado: Universitas Sam Ratulangi.

[20] Bambang Triatmodjo. 2008. Hidrologi Terapan. Yogyakarta: Beta Offset.

[21] Chay Asdak. 2002. Hidrologi dan Pengelolaan Daerah Aliran Sungai. Yogyakarta: Universitas Gajah Mada.

[22] Peraturan Menteri Pekerjaan Umum Nomor 12/PRT/M/2014 Tentang Penyelenggaraan Sistem Drainase Perkotaan. Jakarta: Kementerian Pekerjaan Umum 
